\title{
Toxicity test of desorbed chromium from polluted soil around tannery industry in Yogyakarta-Indonesia by using Brassica juncea and Helianthus annuus $L$.
}

\section{Suherman' ${ }^{*}$, Wina Akmarina', Wulandari Sutiawan', Nurul Hidayat Aprilita', Mudasir' Kinichi Morita²}

\author{
'Department of Chemistry, Faculty of Mathematics and Natural Sciences, Universitas Gadjah Mada, Sekip \\ Utara Kotak Pos 21 BLS Yogyakarta 55281 Indonesia \\ ${ }^{2}$ New Business Development Office, Corporate R\&D Division, Ushio INC. 1-6-5 Marunouchi, \\ Chiyoda-ku, Tokyo 100-8150, Japan.
}

${ }^{*}$ Corresponding author email: suherman.mipa@ugm.ac.id

Received July 23, 2019; Accepted October 10, 2019; Available online November 30, 2019

\begin{abstract}
Indonesia's target to be a new industrial country makes a wide chance in the developing of many industrial sectors. The main problem is the disruption of environmental balance due to poorly managed liquid waste released by the industry. Heavy metal such as chromium $(\mathrm{Cr})$ is the typical pollutant generated from tannery industry in Indonesia. Toxicity test of desorbed chromium ions from polluted soil around tannery industry in YogyakartaIndonesia by using Brassica juncea and Helianthus annuus $L$. has been carried out. In this research, soil samples were divided into four sample points based on the distances from the waste water point sources. Metal content and some physico-chemical properties including ash content, total organic carbon, and cation exchange capacity were determined in this study. Furthermore, the chromium ions adsorption and desorption from polluted soils were investigated and measured by atomic adsorption spectrophotometry (AAS). Thus, ecotoxicity tests of soil eluates from desorption experiments were performed with Brassica juncea and Helianthus annuus L. The results showed that sample III had the highest $\mathrm{Cr}$ content at $916 \mathrm{mg} \mathrm{kg}^{-1}$. The adsorption isotherm of $\mathrm{Cr}$ ions into soils followed Langmuir isotherm with the highest maximum adsorption capacity value at $14.286 \mathrm{mg} \mathrm{kg}^{-1}$ in the sample point IV (unpolluted soil). The optimum desorption of chromium occurred at $\mathrm{pH} 3$. Toxicity test showed that $\mathrm{Cr}$ ions had toxic effect to Brassica juncea and Helianthus annuus $L$.
\end{abstract}

Keywords: Chromium, desorption, toxicity test, tannery industry.

\section{INTRODUCTION}

Tannery industry is an industry that treats a variety of raw leather, semi-finished leathers (pellicle and wet-blue leathers) to become finished leather. Apart from the positive impact, the industrial sector also has a negative impact. The leather tanning industry is categorized as one of the high polluting industries because of tanning activities that have an adverse effect on the environment. This is due to industrial wastes which if not managed properly. In fact, the government has implemented regulations and provisions regarding industrial obligations in processing waste, including those contained in Law of the Republic of Indonesia Number 32 year 2009 concerning Protection and Management of
Environment; also Indonesia Government Regulation Number 101 year 2014 regarding Hazardous and Toxic Waste Management.

Heavy metals are a serious threat today for living things and the environment. Heavy metals can be divided into two categories, namely essential and non-essential elements. All of the two categories have the potential to contain poisons (Nagaiiyoti et al., 2010). As a dangerous chemical, heavy metals are substances that cannot be decomposed and remain behind for long periods of time in the soil. Leather tanning waste water include hazardous waste because they contain heavy metals such as chromium. The leather tanning process can only adsorb $60-80 \%$ chromium, which means that around $20-40 \%$ of 
chromium will be carried in liquid waste and solid waste in the tanning industry (Mayasari and Sholeh, 2016). Thus, significant chromium concentrations are released into the environment through leather tanning industry (Sneddon, 2012).

Andaleeb et al. (2008) stated that the length of germination, roots and shoots decreased with increasing $\mathrm{Cr}$ content in the soil. Suherman et al. (2013) have also conducted research related to the toxicity test of $\mathrm{Cu}$ and $\mathrm{Pb}$ metals from the humus soil of the Harz Mountains (Germany) with Lepidium sativum. The properties of soil eluets slightly reduce the inhibitory effect of $\mathrm{Cu}$ on the growth of Lepidium sativum, especially at low concentrations compared to synthesis solutions. The success of germination depends on external factors. This implies that seeds must be supported by internal sensors capable of sending environmental signals into cellular mechanisms that lead to germination (Leymarie et al., 2009; Bailly et al., 2008; Kranner and Colville, 2011).

This study focuses on the impact of chromium contaminated soil and its effect on seed germination, especially for Brassica juncea and Helianthus annuus L. Studies of soil characteristics and adsorption are needed to determine relation between soil properties and adsorption capacity of contaminated soil. While the desorption study also needed to investigate the possibility of metal distribution in the soil. In addition, toxicity test of chromium needs to be done to evaluate the effect of heavy metals in plant growth.

\section{EXPERIMENTAL SECTION}

\section{Materials}

Soil samples were taken from three different sampling points $(20-40 \mathrm{~cm}$ depth) at Piyungan tannery industry area of Yogyakarta-Indonesia. Sample point IV was appointed as unpolluted soil. The sample point I and II were taken at a location close (side area) to the industrial building, while sample point III just after the outlet of waste water point source. The materials used by pro-analysis qualities from Merck were barium chloride dihydrate $\left(\mathrm{BaCl}_{2} \cdot 2 \mathrm{H}_{2} \mathrm{O}\right)$, magnesium sulfate heptahydrate $\left(\mathrm{MgSO}_{4} \cdot 7 \mathrm{H}_{2} \mathrm{O}\right)$, standard solution of chromium 1,000 mg/L, iron (II) ammonium sulphate (FAS, $\left.\mathrm{Fe}\left(\mathrm{NH}_{4}\right)_{2}\left(\mathrm{SO}_{4}\right)_{2} \cdot 6 \mathrm{H}_{2} \mathrm{O}\right)$, potassium dichromate $\left(\mathrm{K}_{2} \mathrm{Cr}_{2} \mathrm{O}_{7}\right)$, hydrofluoric acid (HF), sulfuric acid $\left(\mathrm{H}_{2} \mathrm{SO}_{4}\right)$, phosphoric acid $\left(\mathrm{H}_{3} \mathrm{PO}_{4}\right)$, indicator of ferroin $\left(\mathrm{C}_{36} \mathrm{H}_{24} \mathrm{FeN}_{6} \mathrm{O}_{4} \mathrm{~S}\right)$, tartaric acid, citric acid, oxalic acid, and Whatman 42 filter paper.

The apparatus in this research are analytical balance (Mattler Toledo AB54-S), digital balance sheet (ACIS AD 300i), shaker (Marius Instrumenten), and oven (Kirin). While instrumentation used are X-ray diffractometer (Shimadzu model XRD-6000), fourier transform infra-red (Hanna H198103), hot plate-stirrer (Thermolyne Cimarec 1), a set of reflux device and an atomic absorption spectrophotometer (AAS, Perkin Elmer 3110 ).

\section{Methods}

Physico-chemical characterization of the soil samples

For the physicho-chemical characterization of the soil samples, the processes were started with the drying step of the 10-15 g samples each at 105 ${ }^{\circ} \mathrm{C}$ for $24 \mathrm{~h}$. The water content of soil samples was determined by the ISO 11465 (1993). Ash content of soil samples were determined by DIN CEN/TS 14775 (2004). Determination of organic carbon was done based on ASTM D 2974 (2000). The electrical conductivity is determined by DIN CEN/TS 15937 (2013). pH of soil samples was measured by the method of ISO 10390 (2005). While cation exchange capacity (CEC) is determined based on DIN ISO 11260 (1997). For functional groups of soil samples, the FTIR method was used for characterization. Data retrieval is repeated three times to calculate the standard deviation.

\section{Metal determination}

Determination of metal content based on the British Standards European Norm (BS EN) 13656 (2002) method. A total of $0.5 \mathrm{~g}$ of soil samples were extracted with the addition of $4 \mathrm{~mL}$ of $40 \%$ $\mathrm{HF}$ solution and shaken for $24 \mathrm{~h}$. The mixture was added $12 \mathrm{~mL}$ of aqua regia and shaken back for $24 \mathrm{~h}$. The filtrate is separated which is then measured by the metal content of the AAS instrument. 


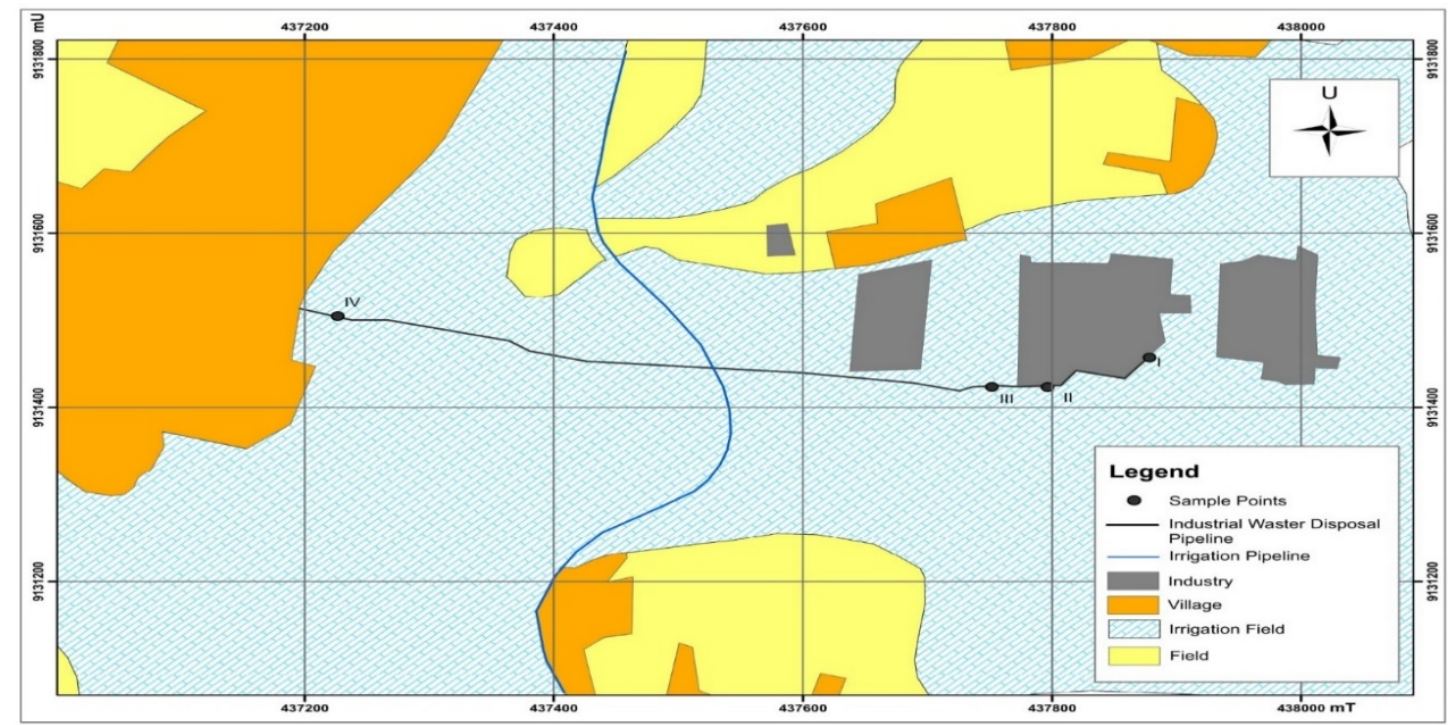

Figure 1. Soil sampling site at Piyungan Yogyakarta-Indonesia

\section{Total $\mathrm{Cr}$ content determination}

A soil sample with a mass of $2 \mathrm{~g}$ was put into a polyethylene bottle which was then added with 50 $\mathrm{mL}$ of aquabides. Furthermore, the $\mathrm{pH}$ of the solution was adjusted with variations in $\mathrm{pH} \mathrm{3,5,7}$ and 9. The mixture was shaken for $24 \mathrm{~h}$ which was then centrifuged at a speed of $5000 \mathrm{rpm}$ for 15 min. The sample was filtered with Whatman 42 filter paper and the filtrate was taken. $\mathrm{Cr}$ concentration in the filtrate after interaction was measured by the AAS instrument. Data retrieval is repeated three times to calculate the standard deviation. The study was carried out at $\pm 27^{\circ} \mathrm{C}$ and a room pressure of $\pm 1 \mathrm{~atm}$.

\section{Chromium toxicity test with Brassica juncea and Helianthus annuus $L$.}

Soil eluets filtered from desorption experiments (with variations in $\mathrm{pH} \mathrm{3,5,7}$ and 9) and aquabides as blank were tested for toxicity with Brassica juncea and Helianthus annuus $\mathrm{L} . \mathrm{Cr}$ synthetic solutions were prepared in pure water containing the same $\mathrm{Cr}$ concentration as desorption of soil eluates. As much as $5 \mathrm{~mL}$ of each solution (both eluates from desorption and synthetic solution) were pipetted into Whatman 42 filter paper which had been placed on the petridish. As a control, the same procedure is carried out with aquabides. A total of 25 seeds from Brassica juncea and Helianthus annuus $L$. are arranged on wet filter paper with a proportional distance from each other. Petridish plates were closed and incubated for germination at room temperature in darkness for 3 days. After 3 days, the root length and hypocotyl from the seeds were measured, then the percent inhibition for each solution concentration was calculated.

\section{RESULTS AND DISCUSSION}

Soil samples used in this study were taken from the soil around tannery industry in Bantul, Yogyakarta. The soil samples studied were top soil with a depth of $0-30 \mathrm{~cm}$. The results for the characterization of physicochemical properties of each soil sample are presented in Table 1.

Table 1 shows that the soil $\mathrm{pH}$ measured using $\mathrm{H}_{2} \mathrm{O}$ extract solution has a higher value than $\mathrm{KCl}$ and $\mathrm{CaCl}_{2}$ salt solutions. This is due to the release of cations when salt is added to the soil suspension. The release of cations will replace hydrogen ions in the soil, so hydrogen ions will be pushed into the soil solution which causes the concentration of the soil to approach the concentration of its natural conditions.

Ashraf et al. (2017) states that soil pH is an important factor that controls the geochemical ability of heavy metals in the solid phase and solution from the soil. Soil $\mathrm{pH}$ determines the adsorption and desorption processes and chemical speciation of $\mathrm{Cr}$ and other heavy metals in the soil. In addition, at high $\mathrm{pH}$ there will be deprotonation of the hydroxyl group of soil components which causes an increase in negative charge on soil binding sites so that metal cations can be adsorbed by soil through electrostatic interactions. Sample point III has the highest $\mathrm{pH}$ value and metal content and at sample point IV has the lowest $\mathrm{pH}$ value and metal content (as unpolluted soil). This evidence showed with the lower $\mathrm{pH}$, metals will be 
easier to leaching and cause thus distribute to a wider range in the soil.

Acidity of soil pH is influenced by the presence of active ions of hydrogen and aluminium ions in soil solutions. This comes from the dissociation of water in the form of $\mathrm{OH}^{-}$and $\mathrm{H}^{+}$, as well as the release of $\mathrm{Al}^{3+}$ from the structure of clay minerals in the adsorption location on colloidal soil. The soil
$\mathrm{pH}$ value in Table 1 is in the range of $\mathrm{pH}$ value 6.17-7.87 with the lowest $\mathrm{pH}$ value owned by sample point IV. The lower $\mathrm{pH}$ of sample IV is possibly due to the presence of $\mathrm{H}^{+}$released due to reaction of $\mathrm{Al}^{3+}$ and water molecules in the soil solution (Verheye, 2009).

Tabel 1. Physico-chemical properties and metal content of the soil samples around tannery Industry

\begin{tabular}{|c|c|c|c|c|}
\hline Parameter & $\begin{array}{l}\text { Sampling } \\
\text { point I }\end{array}$ & $\begin{array}{c}\text { Sampling } \\
\text { point II }\end{array}$ & $\begin{array}{l}\text { Sampling } \\
\text { point III }\end{array}$ & $\begin{array}{c}\text { Sampling point } \\
\text { IV }\end{array}$ \\
\hline \multicolumn{5}{|l|}{$\mathrm{pH}$} \\
\hline a. $\mathrm{H}_{2} \mathrm{O}$ & 7.57 & 7.83 & 7.87 & 6.90 \\
\hline b. $\mathrm{KCl}$ & 7.13 & 6.80 & 7.00 & 6.17 \\
\hline c. $\mathrm{CaCl}_{2}$ & 7.33 & 7.07 & 7.13 & 6.67 \\
\hline $\begin{array}{l}\text { Total organic carbon } \\
\left(\mathrm{mg} \mathrm{C} \mathrm{g}^{-1} \text { soil }\right)\end{array}$ & 34.63 & 43.03 & 42.90 & 45.67 \\
\hline $\begin{array}{l}\text { Soil organic matter } \\
\left(\mathrm{mg} \mathrm{g}^{-1} \text { soil }\right)\end{array}$ & 59.71 & 74.18 & 73.95 & 78.73 \\
\hline $\begin{array}{l}\text { Cation exchange capacity } \\
\text { (meq/100 g) }\end{array}$ & 0.80 & 1.23 & 1.04 & 1.32 \\
\hline Ash content $(\%)$ & 17.62 & 17.10 & 20.69 & 15.23 \\
\hline $\begin{array}{l}\text { Electrical conductivity } \\
\left(\mu \mathrm{S} \mathrm{cm}^{-1}\right)\end{array}$ & 1,329 & 1,978 & 2,533 & 211 \\
\hline \multicolumn{5}{|l|}{ Water content $(\%)$} \\
\hline $\begin{array}{ll}\text { a. } & \text { Room } \\
\text { temperature }\end{array}$ & 8.49 & 10,45 & 16.16 & 9.98 \\
\hline b. $105^{\circ} \mathrm{C}$ & 37.86 & 50.39 & 51.62 & 45.53 \\
\hline Cr total & 459.4 & 706.8 & 916.2 & 167.1 \\
\hline
\end{tabular}

( $\mathrm{mg} \mathrm{kg}^{-1}$ )

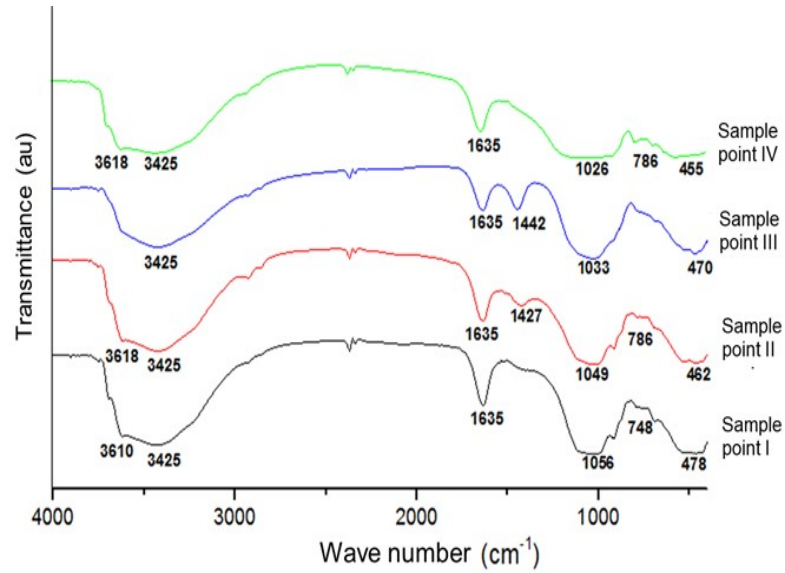

Figure 2. FTIR spectra's of soil samples

Soil organic matter consists of organic carbon (C-organic) as the main constituent component which is as much as $58 \%$ (de Brogniez et al., 2015). Soil organic matter has a functional group that can contribute negative charges to the soil. This negative charge is able to exchange cations in the soil so as to increase soil cation capacity. Cations that are bound in the soil by clays or organic matter can be replaced with other cations. The amount of cation is linearly related to the

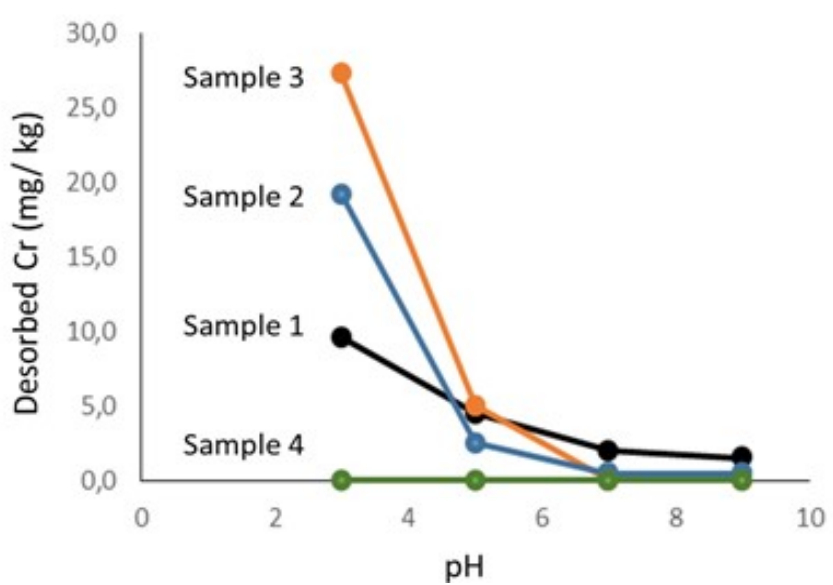

Figure 3. Effect of $\mathrm{pH}$ variation on the $\mathrm{Cr}$ desorption from the soil samples

amount of negative charge in the soil. The CEC results in Table 1 showed that at sample point IV has the highest CEC value. These results indicate that the sample has the highest predominance of negative charge and is proportional to the number of cations that can be bound by the soil. This CEC value can also be correlated with the presence of organic C contained in sample point IV which shows the highest value as well. High levels of organic $C$ indicate the increasing amount of soil 
organic matter with the dominance of negative charges in the soil. As the results from Suherman et al. (2013), soil organic matter will be directly proportional to the value of soil cation exchange capacity (CEC) because soil organic matter will increase the negative charge in the soil with the results of sample point IV having the highest organic matter content and soil CEC.

Ash content shows the quantity of minerals and other inorganic ingredients in the soil. In Table 1 it is shown that soil samples at sample point III have the highest ash content and sample point IV shows the lowest ash content. Determination of ash content is done by heating at high temperatures gradually to a temperature of $550{ }^{\circ} \mathrm{C}$ to oxidize all organic matter. This inorganic material which becomes ash can further be used to bind metal $\mathrm{Cr}$ in the soil when the levels of organic matter are low.

Electrical conductivity is the ability of the soil to conduct electric current. Electrical conductivity in the soil can be associated with the ions contained in it. Soil has the ability to conduct electricity through ions dissolved in the soil. Basically the electrical conductivity of the soil increases with increasing concentration of salts in solution. Electrical conductivity can also be related to the water content contained in it. Water in the soil can solvate ions which can then be exchanged with other ions. Based on Table 1, sample point III has the highest water content. The electrical conductivity values for sample points I, II and III are high because the average soil electrical conductivity is in the order of $10^{3}$ (Rodríguez-Pérez et al., 2011; Suherman et al., 2013). At sample point IV it is in the order of $10^{2}$ because at sample point IV is a sample point of unpolluted soil used as a comparison (with lower metal cationic existence).

The results of chromium analysis in Table 1 showed that there is very high contamination in the soil around the flow of liquid waste from the tannery industry. Sampling point III shows soil samples with the highest $\mathrm{Cr}$ content and sampling point IV have the lowest $\mathrm{Cr}$ content. This is supported by ash content, electrical conductivity and the highest water content possessed by sample point III. The ash content in soil samples represents the content of inorganic material in the soil. At sample point III, the binding of $\mathrm{Cr}$ is carried out by the inorganic material it has. This is supported by the statement of Mandzhieva et al. (2014) that mineral mineral fraction is an important factor in the adsorption of metal cations when the levels of organic matter in the soil are low. Inorganic materials that can play a dc role include Al, which is one of the dominant constituent elements of the soil. In its oxidation form, $\mathrm{Al}_{2} \mathrm{O}_{3}$ is amphoteric (Idrissova \& Tumanova, 2014) so that at low $\mathrm{pH}$ $\mathrm{Al}_{2} \mathrm{O}_{3}$ is a base that is able to bind to metal cations.

Figure 2 shows negative groups that play a role in binding heavy metals in the soil sample. The four spectra show absorption at relatively equal wave numbers. Wave number of $3618 \mathrm{~cm}^{-1}, 3610$ $\mathrm{cm}^{-1}$ and $3425 \mathrm{~cm}^{-1}$ show absorption of $\mathrm{OH}$ groups in carboxylic acids. The absorption band $1635 \mathrm{~cm}^{-1}$ shows the absorption of $\mathrm{OH}$ groups from silanol (Si-OH). The absorption band intensities in the area around $3618 \mathrm{~cm}^{-1}$ and $1635 \mathrm{~cm}^{-1}$ seems to be decreasing due to the reduction of $\mathrm{OH}$ groups on the soils after the adsorption process with metal ions. At sample points II and III which are sample points of contaminated soil there is absorption in the area of $1427 \mathrm{~cm}^{-1}$ and $1442 \mathrm{~cm}^{-1}$ which shows the vibration of bending $\mathrm{C}-\mathrm{H}$. Wave number 1056 $\mathrm{cm}^{-1}, 1049 \mathrm{~cm}^{-1}$ and $1033 \mathrm{~cm}^{-1}$ respectively at sample points I, II and III show absorption for stretching vibrations of $\mathrm{Si}-\mathrm{O}$ and $\mathrm{Si}-\mathrm{O}-\mathrm{Si}$. At sample point IV which is a sample of uncontaminated soil, there is a shift in the absorption band in the wave number area $1026 \mathrm{~cm}^{-1}$. The peaks in the wave numbers of $478 \mathrm{~cm}^{-1}, 462 \mathrm{~cm}^{-1}, 470 \mathrm{~cm}^{-1}$ and 455 $\mathrm{cm}^{-1}$ for sample points I, II, III and IV respectively show Si-O-Si vibration, which indicates that the metal ion in binding to the surface of the soil not only through silanol groups, but also through siloxane groups ( $\mathrm{Si}-\mathrm{O}-\mathrm{Si}$ ).

Figure 3 revealed the phenomenon of declining chromium desorption as $\mathrm{pH}$ increases. The high concentration of chromium desorbed in an acidic condition caused by speciation of $\mathrm{Cr}$ in the soil eluates due to the influence of $\mathrm{pH}$. This is supported by a statement from Dias-Ferreira et al. (2015) that desorption of chromium from soil into the solution is most significant at lower $\mathrm{pH}$. The relatively low concentration of chromium desorbed from highly polluted soil samples $(<100 \mathrm{mg} / \mathrm{kg}$ ) just in comparable number to the previous results of $\mathrm{Zn}$ desorption from illegal land fill area in Yogyakarta (Amaliyah et al., 2019).

\section{Toxicity tests of desorbed chromium by using Brassica juncea and Helianthus annuus $L$. \\ The toxicity test of chromium against Brassica juncea and Helianthus annuus $L$. were studied by germination using eluates solution containing heavy}


metal from the results of desorption variation of $\mathrm{pH}$ of the solution. Although the level of heavy metals in the soil around the tannery industry exceeds the permissible threshold (Table 1), the fraction of metal which is desorbed in soil eluates using a variation of $\mathrm{pH}$ is quite low, as shown in Figure 3. In the toxicity tests with Brassica juncea and Helianthus annuus L., growth of root and hypocotyl were influenced by the presence of $\mathrm{Cr}$ metal in eluates from the desorption experiments.

In the toxicity test with Brassica juncea (Figure 4), growth of root and hypocotyl were influenced by the presence of $\mathrm{Cr}$ solution from the results of desorption experiments. From the toxicity test, there is a direct relationship between the severities of Brassica juncea's growth response with increasing metal concentration. However, at the lowest concentration of $\mathrm{Cr}$ eluates (Figure 4a, unpolluted soil), the eluates support the growth of the root and hypocotyl instead of inhibited the elongation. This phenomena possibly due to the eluates containing the nutrients extracted from the soil samples that stimulate the seedlings growth. In addition, $\mathrm{Cr}$ solution in both eluates and synthetic clearly inhibited the growth of the Brassica juncea. But, the hypocotyl growth responded more sensitive toward $\mathrm{Cr}$ than root growth.

The effect of $\mathrm{Cr}$ eluates and synthetic solution obviously inhibited the growth of Helianthus Annuus L. seedlings as can be seen in Figure 5. At the lowest of $\mathrm{Cr}$ eluates (Figure 5a), the solution caused a positive effect on the seedling growth. This condition just in accordance to the $\mathrm{Cr}$ eluates effect on the Brassica juncea (Figure 4a), that the existence of soil nutrients at the eluates could support germination process. In case of the synthetic solution without DOM (dissolved organic matter) and soil nutrients, the growths (root and hypocotyl) were adversely affected by the presence of chromium solution. And there was strong relationship between the severity of the plant responses and the increasing of $\mathrm{Cr}$ concentration in the synthetic solution.

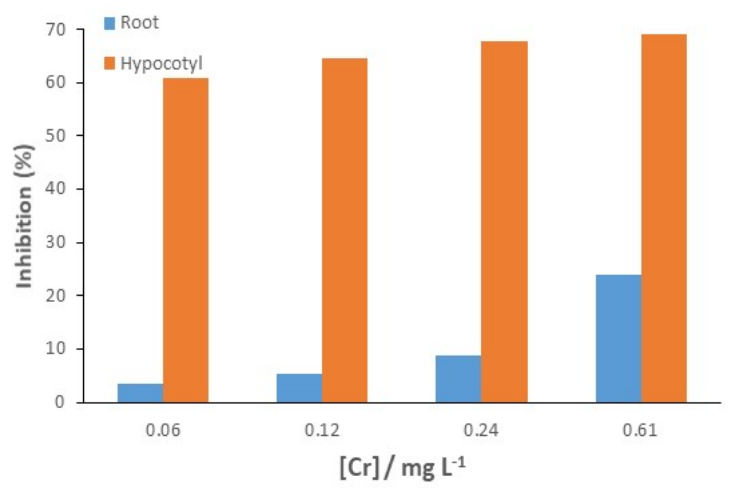

(b)

Figure 4. Toxicity test of $\mathrm{Cr}$ eluates (a) and $\mathrm{Cr}$ synthetic solution to the Brassica juncea (at pH neutral)

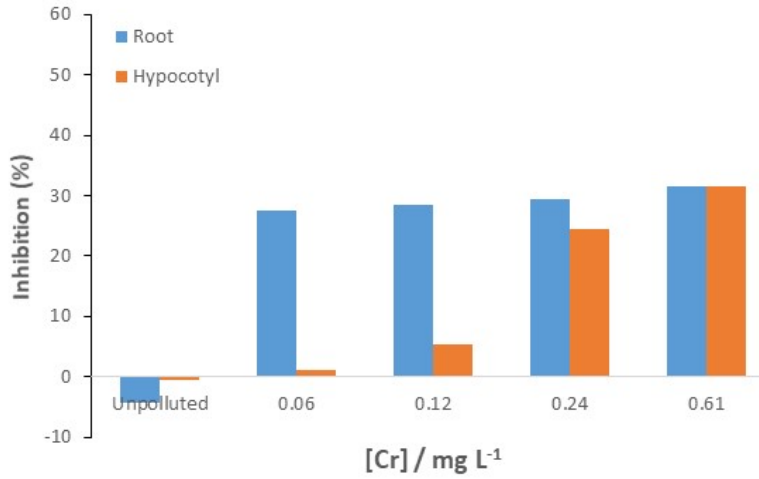

(a)

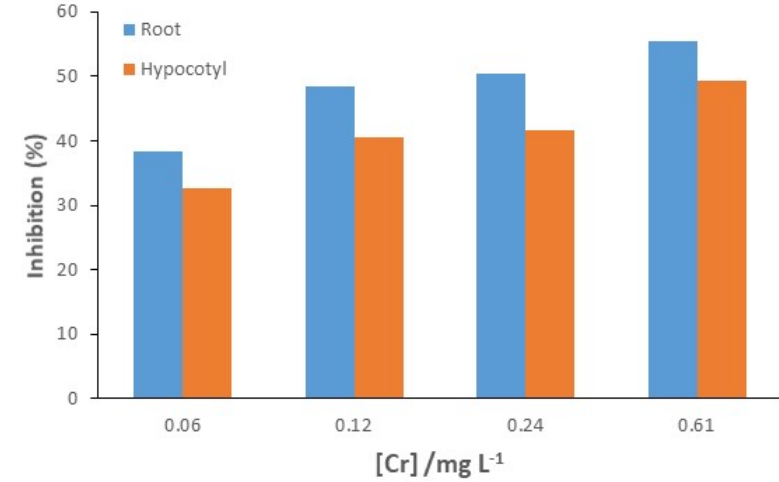

(b)

Figure 5. Toxicity test of $\mathrm{Cr}$ eluates (a) and $\mathrm{Cr}$ synthetic solution to the Helianthus Annuus L. (at pH neutral) 


\section{CONCLUSIONS}

The physicochemical properties of soil samples have a relationship with the profile of chromium concentration, with the condition that all soil sampling sites are highly polluted with the chromium in comparison to the chromium concentration from the unpolluted soil samples (sampling site IV). In the desorption study, it was revealed that chromium was desorbed from the soil structure at the optimum $\mathrm{pH} 3$. Toxicity test shows that $\mathrm{Cr}$ has a toxic effect on Brassica juncea and Helianthus annuus L. Growth (roots and hypocotyl) in plants decreases with the increasing chromium concentration in eluates and synthesis solution.

\section{ACKNOWLEDGEMENTS}

The authors thanks to Ministry of Research, Technology and Higher Education of the Republic Indonesia for financial support through the PDUPT (Penelitian Dasar Unggulan Perguruan Tinggi) research scheme grant with the contract number of 2623/UN1.DITLIT//DIT-LIT/LT/2019.

\section{REFERENCES}

Nagajiyoti, P., Lee, K., \& Sreekanth, T. (2010). Heavy Metals Occurrence and Toxicity for Plants: A Review, Environ. Chem. Lett, 8, 199-216.

Mayasari, H.E., \& Sholeh, M. (2016). Chrome Adsorption in Tannery Wastewater, Jurnal Kimia Mulawarman, 2 (13), 50-56.

Sneddon, C. (2012). Chromium and its Negative Effects on the Environment, Case Study, Department of Earth Sciences, Montana State University, USA.

Andaleeb, F., Muhammad, A.Z., Muhammad, A., \& Zafar, M.K. (2008). Effect of Chromium on Growth Attributes in Sunflower (Helianthus annuus L.), J. Environ. Sci., 20, 1475-1480.

Suherman, S., Schmidt, C., Kolb, M., Zachmann, D., \& Bahadir, M., (2013). Partitioning of Copper and Lead Between Solid and Dissolved Organic Matter in a Humus-Rich Soil of the Harz Mountain (Germany) and Ecotoxicity Test with Lepidium Sativum, Fresen. Environ. Bull., 22(2), 318-327.

Leymarie, J., Benech-Arnold, R.L., Farrant, J.M., \& Corbineau, F. (2009). Thermodormancy and ABA Metabolism in Barley Grains, Plant Signal Behav., 4(3), 205-207.
Bailly, C., El-Maarouf-Bouteau, H., \& Corbineau, F. (2008). From Intracellular Signaling Networks to Cell Death: The Dual Role of Reactive Oxygen Species in Seed Physiology, Comptes Rendus Biologies, 331, 806-814.

Kranner, I. \& Colville, L. (2011). Metals and Seeds: Biochemical and Molecular Implications and Their Significance for Seed Germination, Environ. Exp. Bot., 72(1), 93105.

International Organization for Standarization (ISO) method 11465 (1993).

Determination of Dry Matter and Water Content on a Mass Basis-Gravimetric Method. ISO Central Secretariat, Jeneva.

Deutschen Instituts für Normung-European Committee for Standardization/Technical Specification 14775 (2004). Method for The Determination of Ash Content. The German Institute for Standardization, Berlin.

American Society of Testing and Materials (2000). Standard Test Methods for Moisture, Ash, and Organic Matter of Peat and Other Organic Soils. Philadelphia

Deutschen Instituts für Normung-European Committee for Standardization/Technical Specification 15937 (2013). Determination of Spesific Electrical Conductivity. The German Institute for Standardization, Berlin.

International Organization for Standarization (ISO) method 10390 (2005). Soil QualityDetermination of $\mathrm{pH}$. ISO Central Secretariat, Jeneva.

Ashraf, A., Bibi, I., Niazi, N.K.,Ok, Y.S., Murtaza, G., Shahid, M., Kunhikrishnan, A., \& Mahmood, T. (2017). Chromium(VI) Sorption Efficiency of Acid-Activated Banana Peel over Organo-Montmorillonite in Aqueous Solutions, Int. J. Phytoremediat., 19(7), 605-613.

Verheye, W.H. (2009). Land Use, Land Cover and Soil Sciences: Land Use Management and Case Studies, Eolss Publishers Co. Ltd., Oxford, UK.

de Brogniez, D., Ballabio, C., Stevens, A., Jones, R.J.A., Montanarella, L., \& van Wesemael, B. (2015). A Map of the Topsoil Organic Carbon Content of Europe Generated by a 
Generalized Additive Model, Eur. J. Soil Sci., 66, 121-134.

Rodríguez-Pérez, J.R., Plant, R.E., Lambert J., \& Smart D.R. (2011). Using Apparent Soil Electrical Conductivity (EC) to Characterize Vineyard Soils of High Clay Content, Precis. Agric., 12, 775-794.

Mandzhieva, S., Minkina, T., Pinskiy, D., Baver, T., \& Sushkova, S. (2014). The role of soil's particle-size fractions in the adsorption of heavy metals, Eur. J. Soil. Sci., 3, 197-205.

Idrissova, K.S. \& Tumanova, A.A. (2014). Effect of Solid Fuel Mineral Composition on the Formation of Sour Pulp in Hydro-Slug Removal System of Thermal Power Plants, Eur. Chem. Technol. J., 16, 329-332.
Dias-Ferreira, C., Kirkelund, G. M., \& Ottosen, L. M. (2015). Ammonium citrate as enhancement for electrodialytic soil remediation and investigation of soil solution during the process. Chemosphere, $119,889-895$.

Amaliyah, F.R., Suratman, A., \& Suherman, S. (2019). The Influence of Physico-Chemical Properties on Heavy Metal Content on the Illegal Land Fill Kadisoka, Sleman, Special Region of Yogyakarta, Mater. Sci. Forum, 948, 14-19. 